\author{
Marquette University \\ e-Publications@Marquette
}

College of Nursing Faculty Research and

Publications

Nursing, College of

$9-2011$

\title{
Autism Spectrum Disorder: Parenting Stress, Family Functioning and Health-Related Quality of Life
}

Norah L. Johnson

Marquette University, norah.johnson@marquette.edu

Marilyn Frenn

Marquette University, marilyn.frenn@marquette.edu

Suzanne Feetham

University of Wisconsin - Milwaukee

Pippa Simpson

Children Research Institute

Follow this and additional works at: https://epublications.marquette.edu/nursing_fac

Part of the Nursing Commons

\section{Recommended Citation}

Johnson, Norah L.; Frenn, Marilyn; Feetham, Suzanne; and Simpson, Pippa, "Autism Spectrum Disorder: Parenting Stress, Family Functioning and Health-Related Quality of Life" (2011). College of Nursing Faculty Research and Publications. 125.

https://epublications.marquette.edu/nursing_fac/125 
Marquette University

e-Publications@Marquette

\section{Nursing Faculty Research and Publications/College of Nursing}

This paper is NOT THE PUBLISHED VERSION; but the author's final, peer-reviewed manuscript. The published version may be accessed by following the link in th citation below.

Families, Systems, \& Health, Vol. 29, No. 3 (September 2011): 232-252. DOI. This article is (C) American Psychological Association and permission has been granted for this version to appear in e-

Publications@Marquette. American Psychological Association does not grant permission for this article to be further copied/distributed or hosted elsewhere without the express permission from American Psychological Association.

\section{Autism Spectrum Disorder: Parenting Stress, Family Functioning and Health-Related Quality of Life}

\section{Norah Johnson}

College of Nursing, Marquette University;

\section{Marilyn Frenn}

College of Nursing, Marquette University

\section{Suzanne Feetham}

College of Nursing, University of Wisconsin-Milwaukee;

Children's National Medical Center, Washington, DC

\section{Pippa Simpson}

Children Research Institute, Milwaukee, Wisconsin

Acknowledgement: Funding from the Nurse Practitioner Health Care Foundation/Pfizer and the Milwaukee District Nursing Association Lamplight Scholarship. Recruitment assistance from the Kennedy Krieger Institute's Interactive Autism Network. 
The focus of this study is to understand the relationship of parenting stress, support from family functioning and health-related quality of life: physical and mental health, for both parents of children with Autism Spectrum Disorder (ASD). ASD is a collective term used to represent three Pervasive Developmental Disorders: (1) Autistic Disorder, (2) Pervasive Developmental Disorder, not otherwise specified, and (3) Asperger's Syndrome (Tanguay, 2006). The prevalence of ASD is reported as one out of every 110 Americans (Rice, 2009) resulting in approximately 2.8 million people with ASD in the United States. Symptoms of ASD appear before 3 years of age (American Psychiatric Association [APA], 1994). With the diagnostic criteria of the DSM-IV (APA, 1994), a person is diagnosed with ASD if they exhibit qualitative impairments in social interaction and communication, and restricted, repetitive, and stereotyped patterns of behavior, activities, and interests (APA, 2000). The symptoms of the three disorders range in severity with Autistic Disorder being the most severe. The least severe, Asperger's syndrome, is also referred to as high functioning autism.

Family functioning is an important source of support for the family. The perceptions of family functioning of parents of children with ASD merits direct research. A study that gathers data from female and male parents is most helpful for understanding differences in what parents find stressful, as well as how support from family functioning dynamics are related to parental physical and mental health. This study will help guide the development of appropriate interventions targeted to reduce parental stress, and improve parental physical and mental health outcomes.

Parents of children with ASD are stressed with caring for their child and the decision making that accompanies the care. The children with ASD are dependent on their parents for diagnostic assessment, treatment selection and support (AHRQ, 2009). Parents who are mentally and physically healthy are best prepared to cope with the ramifications of the diagnosis of ASD, and be supportive advocates for their child (Feetham, 2011).

In the present study, support is conceptualized as family functioning. The family science literature cites multiple functions of the family (Friedman, Bowden, \& Jones, 2003). Family functioning includes a commitment to support the functions of the family that include: economic, safety, child rearing, caregiving, and communication Feetham (2007). Support from family functioning is defined as supportive relationships among parents, family members, friends and community members (Roberts \& Feetham, 1982). The social relationships in turn influence health. Parents are part of a family system that functions by appraising, operating, and behaving in certain ways (McCubbin \& Thompson, 1991). Family functioning includes generational relationships, unique sets of rules, priorities, and ethics. The family is also considered to be a mediator between the individual and the environment (Andrews, Bubolz, \& Paolucci, 1980).

Knafl and Deatrick (2003) found that parents' joint effort to manage their child's chronic illness resulted in different views on how to manage the situation. Although the parents work together, they may have different future expectations or a plan on how to get there, which is a potential source of distress (Knafl \& Deatrick, 2003). Within families, there may be differences in expectations about family functioning. However, in most studies, the mother is the only source of data (Cassano, Adrian, Veirs, \& Zaman, 2006). With only one source of data, the differences in expectations, between mother and father, about family functioning are missed. 
Improved quality of life is one recognized metric of a successful outcome (Lantos, 2007), which is crucial in the case of ASD, as it has no cure. Health-related quality of life (HQRL) includes physical and mental health. HRQL refers to the effects of health, illness and treatment on quality of life (Ferrans, Zerwic, Wilbur, \& Larson, 2005). These include biological function, symptoms, functional status, and general health perceptions (Ferrans et al., 2005). Parenting stress impacts the mental and physical health of parents of children with ASD in differing degrees; there can be a negative impact on mental health (Baker, Blacher, \& Olsson, 2005; Phetrasuwan \& Miles, 2009), or both physical and mental health (Allik, Larsson, \& Smedge, 2009; Lee et al., 2006).

\section{THEORETICAL FRAMEWORKS}

This study examined the relationships among the three variables of parenting stress, supportive family functioning and the HRQL (physical and mental health) for parents of children with ASD. The concept that a person's appraisal of their own stress will have an impact on their physical and mental health (HRQL) derives from the Transactional Model of Stress and Coping (Lazarus, 1999; Lazarus \& Folkman, 1984). The concept of family functioning in a supportive role to mediate the potential effect of stress on parental HRQL (physical and mental health) comes from Social Support Theory (Lakey \& Cohen, 2000). Supportive actions of others are effective in reducing the effects of a stressor when the form of the assistance matches the demands of the stressor (Cohen \& McKay, 1984; Cutrona \& Russell, 1990). The effects of social support include a person's adherence to health behaviors and a person's immune response (Lakey \& Cohen, 2000). Our model was developed to test theoretical relationships (see Figure 1) of the three basic concepts we believe to be fundamental: parenting stress, supportive family functioning, and health-related quality of life (physical and mental health).

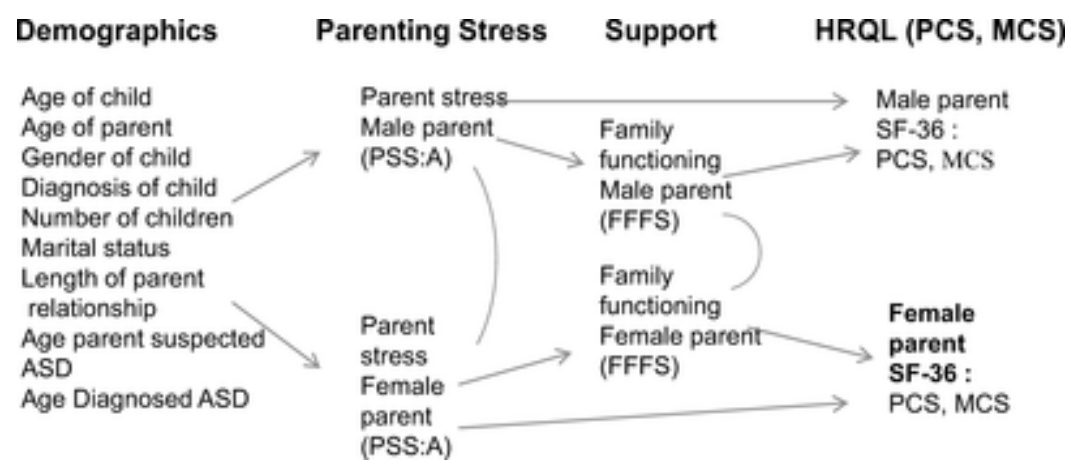

Figure 1. Conceptual Model: Johnson Parenting Health-Related Quality of Life Model.

\section{REVIEW OF LITERATURE}

A systematic review of scientific literature included the following databases: CINAHL, Health Sciences in Proquest, Social Sciences in Proquest, PSYCH info, ERIC, MEDLINE, and Dissertations and theses abstracts. The search terms were: autism, dyads, social support, stress, family functioning, healthrelated quality of life, and well-being.

\section{PARENTING STRESS}

Prior research revealed three foci of stress in parents of children with ASD (1) parenting a child with ASD is more stressful than parenting other children; (2) the behaviors of children with ASD are the 
principal stressors; (3) mothers of children with ASD perceive more stress than fathers. Parents of children with ASD are more stressed than parents of children without ASD, as reported in three studies with a range of participants ( $n=18$ to $n=151$ ) and stress measures. Herring, Gray, Taffe, Sweeny, and Einfeld (2006) used a 0-4 Likert scale with the poles "no stress" to "very stressed." Konstantareas and Papageorgiou (2006) used a Clarke modification of Holroyd's Questionnaire on Resources and Stress (QRS). Brobst, Clopton, and Hendrick (2009) measured parenting stress with the Parenting Stress Index-Short Form (PSI-SF) (Abidin, 1995). Herring and Brobst included mothers and fathers, while the other two studies only included mothers.

Severity of the symptoms of ASD (functional impairments and child behavior problems) was associated with parental stress in four studies, using different measures. Tobing and Glenwick (2006) ( $n=97$ mothers of children with ASD) measured stress with the PSI-SF (Abidin, 1995). Hastings and Johnson (2001) ( $n=141$ ) used the Questionnaire on Resources and Stress (QRS)-Friedrich Short Form (Friedrich, Greenberg, \& Crnic, 1983). Herring et al. (2006) ( $n=151)$ reported both behavior and emotional problems contributed to parenting stress, as measured with a 0-4 Likert scale. Konstantareas and Papageorgiou (2006) used the Clarke Modification of Holroyd's QRS: 43 mothers reported more stress with parenting nonverbal, low-functioning, in-flexible, and active children with ASD, than higher functioning children. A Parenting Stress Scale: Autism was developed to assess the particular stressors of parents of children with ASD (Phetrasuwan, 2003). In the study of 103 mothers of children with ASD (Phetrasuwan, 2003), the unusual fears of children and trouble adapting to change were reported as stressing mothers the most.

Mothers of children with ASD perceived more stress than fathers in two studies. Herring et al. (2006) ( $n=72$ fathers and 34 mothers) accessed fathers of children with ASD early in the diagnostic evaluation process. Little (2002) reported an Internet-recruited sample of mothers and fathers ( $n=103$ couples) of children with Asperger's Syndrome and nonverbal learning disorders. Mothers reported more stress, as measured by the QRS, than fathers. The amount of time a parent spent with the child was not reported in either study.

\section{SUPPORT FROM FAMILY FUNCTIONING}

Family functioning for parents of children with ASD was examined in two studies. Parents reported struggles with their extended family members ( $n=26$ mother-father dyads) (Altiere \& Von Kluge, 2009) and more mothers than fathers perceived that the family accessed support during a crisis. Family functioning was measured with the Family Adaptability and Cohesion Evaluation Scales-III (FACES-III) (Olson et al., 1985). Bromley, Hare, Davison, and Emerson (2004) reported that single mothers of male children with ASD and those living in poor housing $(n=68)$, perceived lower levels of social support than parents of female children or those living in better housing conditions. The Family Support Scale, developed by the authors for the study, measured social support. Therefore, a parent's access to support may be related to socioeconomic or relationship variables.

Parents of children with ASD may lack the support they expect from their extended family. For example, Easter Seals (2009) surveyed 1652 (8\% male, 92\% female) parents of children age 30 or younger with ASD. The majority $(80 \%, n=3745)$ of the parents reported that they received little support from their extended families, but $40 \%(n=1872)$ did receive some support from the government such as special education and Medicaid. For the children in the Study 18 years of age or 
younger ( $n=1496), 78 \%$ ( $n=1167$ ) of their parents were extremely or very worried about their financial future. Furthermore, in a Web-based study, 4,682 parents ( $88 \%$ mothers) of children with ASD, parents rated the impact of having a child with ASD on the couple's relationship as somewhat or very negative for $60 \%(n=2472)$ of mothers and $54 \%(n=303)$ of fathers, with the division of labor being the most common contributor to marital conflict (IAN, 2009).

\section{HRQL: PHYSICAL AND MENTAL HEALTH}

Parents of children with ASD may be less mentally and physically healthy than parents of other children. Physical and mental health was measured in two studies for parents of children with ASD. Lee et al. (2009) ( $n=65$ mothers, $n=24$ fathers) reported significantly lower physical health summary component scores and mental health component scores than parents of typically developing children ( $n=46)$, as measured by the MOS 36-item short-form health survey (Ware \& Sherbourne, 1992). In a study of 31 mothers and 30 fathers of children with Asperger's syndrome, Allik, Larsson, and Smedge (2006) found that mothers reported poorer physical health, as measured by the 12-item Short Form Health Survey (SF-12) (Ware, Kosinski, \& Keller, 1996), than the control group mothers of typically developing children or the fathers of the children with Aspergers (Allik, Larsson, \& Smedje, 2006). Therefore, there may be gender differences related to physical and mental health outcomes in parents of children with ASD.

Research has focused on the mental health of mothers of children with ASD and on the mediators of parental mental health. Mental health for mothers of children with ASD was reported in three studies using different measures. Baker et al. (2005) ( $n=214)$ used the Family Impact Questionnaire (Donenberg \& Baker, 1993). Phetrasuwan and Miles $(n=103)$ used the Psychological Well Being Scale (Ruff \& Keyes, 1995), and Bromley et al. (2004) ( $n=68)$ used the 1999 ONS Survey (Meltzer, Gatward, Goodman, \& Ford, 2000). Kersh, Hedvat, Hauser, and Warfield (2006) reported that for mothers and fathers of children with developmental disabilities ( $n=67$ dyads), greater marital quality predicted lower parenting stress and fewer depressive symptoms above and beyond socioeconomic status, child characteristics, and social support. Mental health was measured by the Center for Epidemiologic Studies Depression Scale (CES-D) (Randolph, 1977). Interestingly, the child's overall level of functioning did not predict any measure of parental well-being (Kersh et al., 2006) for mothers or fathers, suggesting that marital quality may be an important source of support for parents caring for the most challenging children with ASD.

Differences in expectations about support from family functioning may mediate parenting stress and physical and/or mental health. No studies looked at differences in family functioning for both parents of children with ASD. In the present study, data on the differences in supportive family functioning will be reported for both parents. The support from the parental relationship is of particular interest based on the review of the literature that demonstrates the greater perceived parenting stress for mothers over fathers.

\section{CURRENT RESEARCH}

This study was designed to address the gaps in the science concerning the relationships of support from family functioning, parenting stress and parental HRQL (physical and mental health) in families 
with children with ASD. Specifically the aims of the study were to investigate the following research questions for both male and female parents of children with ASD:

1. Is parenting stress associated with mental or physical health?

2. Is a wide discrepancy in expectations about family functioning associated with lower mental or physical health?

3. Does discrepancy in expectations of family functioning mediate the relationship of stress on mental or physical health?

Two specific hypotheses for this study were: (1) Highly discrepant parents' scores within spouse perceptions of "what is" and "what should be" in family functioning will be associated with lower mental and physical health; (2) Female parents will have significantly greater discrepancy scores in family functioning than fathers.

\section{METHOD}

\section{Procedure}

A nonexperimental, cross sectional, correlational design was used in the study. Both parents were asked to fill out questionnaires. The objective of the study was to gain a better understanding of the relationship of parenting stress, support from family functioning and HRQL (physical and mental health) for both parents of children with ASD. Approval for the study was obtained from the human research review boards at both the University and a freestanding children's hospital in the Midwest. Data were collected over the Internet via a Web-based site (www.surveymonkey.com) that housed the electronic version of the questionnaires and a description of the study. The researcher's e-mail address was provided in the call for participants as well as log in information to go to the study's online Web site. The participant read the cover letter describing the research study, accepted the terms of a consent form and then completed the demographic form and each questionnaire. Confidentiality was maintained by not using personal identifiers on the questionnaire. Participants created their own numeric identifier. The consent form wording included text that instructed the participant to ask their spouse to fill out a set of questionnaires, however, verification that questionnaires were completed by both parents separately was not possible. Spouses were matched based on the numeric identifiers.

\section{Sample}

The 64 female and male partner parents were recruited from across the United States via autism listserves, social networking sites, autism blogs, hospital clinics, and autism conferences. Subjects were also recruited with the assistance of the Interactive Autism Network (IAN) Research Database at the Kennedy Krieger Institute and Johns Hopkins Medicine Baltimore, sponsored by the Autism Speaks Foundation. A recruitment flyer directed participants to the Internet Web site for access to the study. Inclusion criteria were being the biological parent of one or more children, 2-18 years old, with a diagnosis of ASD (Autism, PDD-NOS, or Asperger's syndrome), Internet access, residence in the U.S., and the ability to identify a spouse or significant other. There were no exclusion criteria. Demographics were collected to describe the sample of participants who reported being a parent. 


\section{Measures}

In addition to the demographic questions, participants were also asked to complete three surveys to measure the key constructs of the study: Parenting stress, supportive family functioning, and HRQL (physical health and mental health). The data collected from both parents were used for this report.

\section{Parenting Stress}

Parenting stress was measured with the Parenting Stress Scale: Autism (Phetrasuwan, 2003). This 28item questionnaire captures stressful parental experiences in four subscales (Phetrasuwan, 2003). The Behaviors and Communication subscale includes questions related to the stress dealing with behaviors problems in public, helping the child learn how to be with other children, learning how to best communicate with the child, helping the child communicate with others and trying to figure out what their child needs or wants during a tantrum. The parental caregiving (caring, protecting) subscale questions relate to feelings about the child not wanting to be touched, problems related to eating, managing sleep problems, bathing and dressing difficulties, how to discipline the child, overcoming feelings of protectiveness, keeping life as normal as possible, and keeping the child on a regular routine. The advocating for the child's needs subscale questions relate to communicating to the day care, school, or health care professionals about the child's special needs. The personal and family life subscale questions include items such as financial problems, and finding time for their own activities. For each question, parents rated their stress from $1=$ not stressful, to $5=$ extremely stressful. Responses were summed to form a total score, and reported as a mean total score, ranging from 0 to 140. Higher scores indicated higher stress. Phetrasuwan (2003) examined the content and face validity of the PSS:A by asking parents and professionals working with children to review the tool and comment on its comprehensiveness, clarity, appropriateness, and level of understandability. Cronbach's alpha for the entire scale in the one study ( $n=108$ ) was .94 (Phetrasuwan \& Miles, 2009). In the present study Cronbach's alpha was 0.95 for males and 0.94 for females.

\section{Support From Family Functioning}

The Feetham Family Functioning Survey (FFFS) was used to measure support from family functioning (Feetham \& Humenick, 1982). The FFFS includes dimensions of family relationships and outside supports. Since 1984, The FFFS has been used in 70 published reports in Japan, U.S., U.K., South Africa and Australia. The FFFS measures the family members' perception of their response to any child, regardless of their condition. The survey consists of 25 items, and is designed to be self-administered in approximately $10 \mathrm{~min}$ (Roberts \& Feetham, 1982; Sawin \& Harrigan, 1995). Three areas of family functions are assessed and supported through factor analysis: (1) relationship between the family and broader social units, such as schools and work outside the home; (2) relationships between the family and its subsystems, such as the division of labor; (3) relationships between the family and the individual, focusing on the reciprocal relationships between husband and wife and between parents and children (Roberts \& Feetham, 1982).

Each item includes a stem item of a family function, followed by three questions: (1) how much there is (2) how much there should be, and (3) how important is this to you? An example of an item is: "The amount of time you spend with your spouse/partner." Each item has seven response options; where 1 represents "little" and 7 represent "much." There are also two open ended questions "What is most difficult for you now?" and "What is most helpful to you now?" Scoring for the FFFS is as follows: First 
the discrepancy score is determined for each item. The difference between the (1) and (2) score for each item is converted to an absolute score. Next, the discrepant scores from each item are summed for an instrument score. The total family functioning survey discrepancy score can range from a possible score of 0 to 126 . A high score $D$ score indicates a higher discrepancy between the respondents' perception of what is, from their perception of what should be. The importance score is not included in the instrument score (Roberts \& Feetham, 1982). The scoring allows the assessment of individual dissonance or dissatisfaction among or within the three major areas of family relationships (Roberts \& Feetham, 1982). A higher score indicates higher discrepancy between desired and present functioning. Cronbach's alpha reliability coefficients for the present study were .91 for males and .90 for females.

\section{HRQL: Physical and Mental Health}

The Rand SF 36-Item Health Survey (Version 1.0) was used to measure physical and mental health as two distinct components. The tool has 36 items that cover eight health concepts. These concepts are: physical functioning (10 items), bodily pain ( 2 items), role limitations because of health problems ( 4 items), role limitations because of personal or emotional problems (3 items), emotional well being (5 items), social functioning ( 2 items), energy/fatigue ( 4 items), general health perceptions (5 items), and a single item that provides an indication of perceived health. Cronbach's alpha reliability coefficients for subscales in the present study ranged from .81 to .93. First, eight separate scores were calculated. Twenty-nine questions were rated on a Likert scale ranging from 3 to 6 points, and seven questions are yes/no. All questions were recoded to $0-100 \%$ representations according to a scoring guide (Ware, Kosinski, \& Keller, 1994). Next, an additional scoring technique for the HRQL instrument yielded two scores: the physical component score (PCS) and the mental component score (MCS). The eight subscale scores were standardized according to the formulas in the user's manual. Psychometrically based summary measures aggregate the eight concepts with different weights to two components, the PCS (Cronbach's $\alpha=.91$ ) and the MCS (Cronbach's $\alpha=.92$ ), without substantial loss of information (Ware, Kosinski, \& Keller, 1994). The mean scores for both the PCS and the MCS of the general U.S. population are $50(S D=10)$ (Ware, Kosinski, \& Keller, 1994).

\section{Statistical Analysis}

Participants completed the surveys at the www.surveymonkey.com Web site. The data were entered by the participant and automatically entered into an Excel spread sheet. The Excel file was imported to SPSS 16.0 (SPSS, 2008). Each participant had the opportunity to fill out demographics and the three surveys. Each survey began with the same seven questions for matching purposes, for identification of the male-female parent couples, while allowing for anonymity. The questions included: gender, birth month of oldest child with ASD, month of respondent's birthday, month of spouse/partner's birthday, initial of respondent's first given name, initial of spouse/partner's first given name and the current state of residence. Male-female parent couples were identified visually by the statistician by looking at the data set for the seven matches. Participants $(n=128)$ who completed all four surveys were used for the data analysis.

Checks for agreement between male and female parents were performed on gender of their child, age of diagnosis, and the diagnosis. Gender of the child did not match in one case. Diagnosis of child 
differed in one case. Age of diagnosis differed in five cases. For discrepant information the females' viewpoint was used.

Descriptive statistics were used in analyzing demographic data, the severity of ASD, family functioning, and for each scale or survey. Discrepancies scores (D scores) were calculated for the items on the FFFS. The D score is equal to the absolute score of the (a) "what is score" minus the (2) 'how much there should be' score. The D score was computed for each item and summed for each respondent.

Pearson $r$ correlations were used to examine zero order correlations for all of the study variables: demographics, stress, family functioning D score, and parental HRQL (PCS and MCS separate). Significant correlations were used in further analyses. Multiple regressions for male and female SF 36 subscales will all variables included with and without D score were run first. Then, stepwise linear regression was used to develop models to predict mental and physical component scores of the HRQL measure. Backwards linear regression was done as a check.

A Wilcoxon signed-ranks test was performed to detect differences between the two related groups (males' and females' scores for the discrepancy between what is and should be FFFS). Baron and Kenney's (1986)mediation steps were followed in establishing mediation models ( $X$ = parenting stress; $M=D$ score of the FFFS survey; and $Y=P C S, M C S)$. If the effect of the stress parameters decreased, the $D$ scores would be considered a mediator for the stress effect on HRQL (PCS and MCS).

\section{RESULTS}

\section{Study Participants}

The number of respondents who completed all aspects of the study was 64 male and 64 female parents. The majority of the respondents were white ( $n=60$ males, 95\%, $n=60$ females, 95\%), married ( $n=60,94 \%$ ), college graduates ( $n=40$ males, 63\%, $n=44$ females $69 \%$ ). The length of the relationship for the parents ranged from 2-31 years $(M=14.3, S D=5.8)$. The number of the children in the home ranged from $1-5(M=2.2, S D=0.8)$. Fathers in this study were between 25 and 64 years of age $(M=$ $42, S D=7.8)$. Mothers were between 29 and 69 years of age $(M=39.2, S D=7.2)$. The children in the study ranged in age from 2 to 24 years of age $(M=7.8, S D=3.9)$. Most were male $(81 \%)$, and had a diagnosis of Autism (62\%), or PDD-NOS (21\%), or Aspergers (17\%).

\section{Descriptive Statistics}

Results of parenting stress, family functioning discrepancy (D) score, and MCS and PCS are reported in Tables 1 and 2. Overall, both male and female parents reported somewhat to moderate amounts of parenting stress. The highest mean stress subscale scores were on the personal and family life subscale for both males and females. Both male and female parents had a high discrepancy (D) score for 'how much there is now' and 'how much there should be' family functioning. Both males and females had low levels on the mental health component and normative scores of 50 (Ware et al., 1994) on the physical health component of the Rand 36 item Health Inventory. Females (MCS $=34.21 \pm 13.11$ ) had lower scores than males (MCS $=41.60 \pm 12.93)$. 
Table 1

Means and SDs for the Female Parent Stressor Scale: Autism Scale, Feetham Family

Functioning Survey (FFFS), and Physical Health Component (PCS) and Mental Health

Component (MCS) of the Rand 36-Item Heath Survey

\begin{tabular}{lcc}
\hline & Mean $(S D)$ & Range \\
\hline Parental Stressor Scale: Autism $(N)^{*}$ & & \\
$\quad$ Total scale (59) & $83.27(24.97)$ & $20-137$ \\
Subscales & $19.95(5.34)$ & \\
$\quad$ Behavior and communication (62) & $11.88(4.41)$ & $4-30$ \\
$\quad$ Advocating for needs (64) & $20.19(7.85)$ & $5-40$ \\
$\quad$ Parental care giving (63) & $31.71(11.12)$ & $5-49$ \\
$\quad$ Personal and family life (62) & $131.58(22.33)$ & $71-174$ \\
Feetham Family Functioning Survey $(N=64)^{*}$ & $41.97(21.14)$ & $2-95$ \\
$\quad$ Total scale C score & & \\
$\quad$ Total D score (A-B) & $49.10(11.22)$ & $23.30-69.80$ \\
PCS and MCS of Rand 36-item heath $(N=59)^{*}$ & $34.21(13.11)$ & $6.00-58.90$ \\
$\quad$ PCS & & \\
MCS & &
\end{tabular}

Note. $\mathrm{A}=$ How much there is family functioning, $\mathrm{B}=$ How much there should be family functioning, $\mathrm{C}=$ How important it is, $\mathrm{D}=\mathrm{A}-\mathrm{B}$.

"Complete data on all measures was not available.

Table 1. Means and SDs for the Female Parent Stressor Scale: Autism Scale, Feetham Family Functioning Survey (FFFS), and Physical Health Component (PCS) and Mental Health Component (MCS) of the Rand 36-Item Heath Survey

\begin{tabular}{|l|c|c|}
\hline & Mean (SD) & Range \\
\hline Parental Stressor Scale: Autism $(N)^{*}$ & & \\
\hline Total scale (59) & $83.27(24.97)$ & $20-137$ \\
\hline Subscales & & \\
\hline Behavior and communication (62) & $19.95(5.34)$ & $6-30$ \\
\hline Advocating for needs (64) & $11.88(4.41)$ & $4-20$ \\
\hline Parental care giving (63) & $20.19(7.85)$ & $5-40$ \\
\hline Personal and family life (62) & $31.71(11.12)$ & $5-49$ \\
\hline Feetham Family Functioning Survey $(N=64)^{*}$ & & \\
\hline Total scale C score & $131.58(22.33)$ & $71-174$ \\
\hline Total D score (A-B) & $41.97(21.14)$ & $2-95$ \\
\hline PCS and MCS of Rand 36-item heath $(N=59)^{*}$ & & \\
\hline PCS & $49.10(11.22)$ & $23.30-69.80$ \\
\hline MCS & $34.21(13.11)$ & $6.00-58.90$ \\
\hline
\end{tabular}

Note. $\mathrm{A}=$ How much there is family functioning, $\mathrm{B}=$ How much there should be family functioning, $\mathrm{C}_{-}$How =important it is, $\mathrm{D}=\mathrm{A}-\mathrm{B}$.

* Complete data on all measures was not available. 
Table 2

Means and SDs for the Male Parent Stressor Scale: Autism Scale, Feetham Family Functioning Survey (FFFS), and Physical Health Component (PCS) and Mental Health Component (MCS) of the Rand 36-Item Heath Survey

\begin{tabular}{lcc}
\hline & Mean $(S D)$ & Range \\
\hline Parental Stressor Scale: Autism $(N)^{*}$ & $71.18(25.70)$ & \\
$\quad$ Total scale (61) & $17.78(5.54)$ & $25-130$ \\
Subscales & $9.73(4.09)$ & $6-29$ \\
$\quad$ Behavior and communication (64) & $18.16(7.67)$ & $0-19$ \\
$\quad$ Advocating for needs (63) & $25.74(11.68)$ & $5-37$ \\
Parental care giving (63) & $117.84(23.57)$ & $0-49$ \\
$\quad$ Personal and family life $(62)$ & $33.06(20.11)$ & $50-168$ \\
Feetham Family Functioning Survey $(N=64)^{*}$ & & $0-94$ \\
$\quad$ Total scale C score & $51.16(9.56)$ & $20.50-65.10$ \\
Total D score (A-B) & $41.60(12.93)$ & $8.20-62.30$ \\
PCS and MCS of Rand 36-item $(N=61)^{*}$ & & \\
PCS & & \\
MCS &
\end{tabular}

Note. $\mathrm{A}=$ How much there is family functioning, $\mathrm{B}=$ How much there should be family functioning, $\mathrm{C}=$ How important it is, $\mathrm{D}=\mathrm{A}-\mathrm{B}$.

"Complete data on all measures was not available.

Table 2. Means and SDs for the Male Parent Stressor Scale: Autism Scale, Feetham Family Functioning Survey (FFFS), and Physical Health Component (PCS) and Mental Health Component (MCS) of the Rand 36-Item Heath Survey

\begin{tabular}{|l|c|c|}
\hline & Mean (SD) & Range \\
\hline Parental Stressor Scale: Autism $(N)^{*}$ & & \\
\hline Total scale (61) & $71.18(25.70)$ & $25-130$ \\
\hline Subscales & & \\
\hline Behavior and communication (64) & $17.78(5.54)$ & $6-29$ \\
\hline Advocating for needs (63) & $9.73(4.09)$ & $0-19$ \\
\hline Parental care giving (63) & $18.16(7.67)$ & $5-37$ \\
\hline Personal and family life (62) & $25.74(11.68)$ & $0-49$ \\
\hline Feetham Family Functioning Survey $(N=64)^{*}$ & & \\
\hline Total scale C score & $117.84(23.57)$ & $50-168$ \\
\hline Total D score (A-B) & $33.06(20.11)$ & $0-94$ \\
\hline PCS and MCS of Rand 36-item $(N=61)^{*}$ & & \\
\hline PCS & $51.16(9.56)$ & $20.50-65.10$ \\
\hline MCS & $41.60(12.93)$ & $8.20-62.30$ \\
\hline
\end{tabular}

Note. A How much there is family functioning, $\mathrm{B}=$ How much there should be family functioning, $\mathrm{C}=\mathrm{How}$ important it is, $D=A-B$.

* Complete data on all measures was not available.

\section{Correlations}

Correlations of the key study variables are found in Table 3. For parenting stress, all four subscales of the PSS:A correlated for the male-female partners: advocating for child's needs $(r=.32, p=.05)$, behavior and communication $(r=.43, p=.01)$, parental caregiving $(r=.39, p=.01)$, and personal and family life $(r=.45, p=.01)$. 
Table 3

Correlational Analysis of All Key Variables for Males and Females in Hypothesized Model

\begin{tabular}{|c|c|c|c|c|c|c|c|c|c|c|c|c|c|c|}
\hline & 1 & 2 & 3 & 4 & 5 & 6 & 7 & 8 & 9 & 10 & 11 & 12 & 13 & 14 \\
\hline 1. Stress advocate male & 1 & & & & & & & & & & & & & \\
\hline 2. Stress advocate female & $.32^{*}$ & 1 & & & & & & & & & & & & \\
\hline 3. Stress B/C male & $.60^{* *}$ & .23 & 1 & & & & & & & & & & & \\
\hline 4. Stress B/C female & $.34^{* *}$ & $.68^{* *}$ & $.43^{* \bullet}$ & 1 & & & & & & & & & & \\
\hline 5. Stress care give male & $.52^{* *}$ & $.27^{\circ}$ & $.74^{\circ \bullet}$ & $.39^{\circ *}$ & 1 & & & & & & & & & \\
\hline 6. Stress care give female & .21 & $.70^{* *}$ & $.27^{*}$ & $.66^{* *}$ & $.45^{* *}$ & 1 & & & & & & & & \\
\hline 7. Stress PL male & $.60^{* *}$ & .20 & $.74^{* \bullet}$ & $.32^{\circ}$ & $.76^{+*}$ & $.34^{*+}$ & 1 & & & & & & & \\
\hline 8. Stress PL female & $.39^{\circ+}$ & $.69^{\circ *}$ & $.32^{\circ}$ & $.65^{* *}$ & $.41^{* *}$ & $.76^{* *}$ & $.45^{*+}$ & 1 & & & & & & \\
\hline 9. Total male D score & $.29^{\circ}$ & .10 & $.49^{\circ+}$ & .25 & $.29^{*}$ & .14 & $.49^{*+}$ & .21 & 1 & & & & & \\
\hline 10. Total female D score & $.34^{*+}$ & $.58^{* *}$ & $.50^{* *}$ & $.57^{* *}$ & $.49^{* *}$ & $.57^{* *}$ & $.50^{* *}$ & $.70^{* *}$ & $.44^{* *}$ & 1 & & & & \\
\hline 11. MCS male & -.23 & -.20 & -.25 & -.07 & $-.32^{*}$ & -.03 & $-.38^{* *}$ & -.21 & $-.55^{* \bullet}$ & $-.27^{\circ}$ & 1 & & & \\
\hline 12. MCS female & -.17 & $-.42^{* *}$ & -.25 & $-.34^{\circ}$ & -.21 & $-.48^{*+}$ & $-.28^{\circ}$ & $-.52^{* \bullet}$ & $-.52^{* *}$ & $-.58^{\circ *}$ & $.31^{*}$ & 1 & & \\
\hline 13. PCS male & .12 & .06 & .00 & .22 & .18 & .24 & .15 & $.27^{*}$ & -.19 & .08 & -.13 & -.14 & 1 & \\
\hline 14. PCS female & -.11 & $-.41^{* \bullet}$ & -.01 & $-.36^{* *}$ & -.03 & $-.41^{+*}$ & -.00 & $-.30^{\circ}$ & -.05 & $-.37^{* *}$ & -.26 & .12 & -.00 & 1 \\
\hline
\end{tabular}

Note. $\quad \mathrm{B} / \mathrm{C}=$ Behavior and communication; $\mathrm{PL}=$ Personal Life; MCS = Mental health component of the Rand 36 item Health Inventory

Version 1.0; PCS = Physical health component of the Rand 36 item Health Inventory Version 1.0.

"Correlation is significant at the 0.05 level two-tailed. " Correlation is significant at the 0.01 level two-tailed.

Table 3. Correlational Analysis of All Key Variables for Males and Females in Hypothesized Model

\begin{tabular}{|c|c|c|c|c|c|c|c|c|c|c|c|c|c|c|}
\hline & 1 & 2 & 3 & 4 & 5 & 6 & 7 & 8 & 9 & 10 & 11 & 12 & 13 & 14 \\
\hline $\begin{array}{l}\text { 1. Stress } \\
\text { advoc } \\
\text { ate } \\
\text { male }\end{array}$ & 1 & & & & & & & & & & & & & \\
\hline $\begin{array}{l}\text { 2. Stress } \\
\text { advoc } \\
\text { ate } \\
\text { femal } \\
\text { e }\end{array}$ & $.32^{*}$ & 1 & & & & & & & & & & & & \\
\hline $\begin{array}{l}\text { 3. Stress } \\
\mathrm{B} / \mathrm{C} \\
\text { male }\end{array}$ & 60 & .23 & 1 & & & & & & & & & & & \\
\hline $\begin{array}{l}\text { 4. Stress } \\
\mathrm{B} / \mathrm{C} \\
\text { femal } \\
\mathrm{e}\end{array}$ & $\begin{array}{l}334 \\
* * 4\end{array}$ & $\begin{array}{l}68 \\
* * *\end{array}$ & 443 & 1 & & & & & & & & & & \\
\hline $\begin{array}{l}\text { 5. Stress } \\
\text { care give } \\
\text { male }\end{array}$ & .52 & .27 & .74 & $.39_{*}$ & 1 & & & & & & & & & \\
\hline $\begin{array}{l}\text { 6. Stress } \\
\text { care give } \\
\text { female }\end{array}$ & .21 & .70 & \$27 & $.66_{*}$ & .45 & 1 & & & & & & & & \\
\hline $\begin{array}{l}\text { 7. Stress } \\
\text { PL male }\end{array}$ & .60 & .20 & \begin{tabular}{|l|}
.74 \\
\end{tabular} & $2^{3}$ & .76 & $.34_{*}$ & 1 & & & & & & & \\
\hline $\begin{array}{l}\text { 8. Stress } \\
\mathrm{PL} \\
\text { female }\end{array}$ & .39 & .69 & .32 & $.65_{*}$ & .41 & $.76_{*}$ & $.45_{*}$ & 1 & & & & & & \\
\hline $\begin{array}{l}\text { 9. Total } \\
\text { male D } \\
\text { score }\end{array}$ & 29 & .10 & \begin{tabular}{|l|}
.49 \\
\end{tabular} & $\begin{array}{l}.2 \\
5\end{array}$ & .29 & $\begin{array}{l}.1 \\
4\end{array}$ & $.49_{*}$ & .21 & 1 & & & & & \\
\hline $\begin{array}{l}\text { 10. Total } \\
\text { female D } \\
\text { score }\end{array}$ & .34 & .58 & .50 & $.57_{*}$ & .49 & $.57_{*}$ & $.50_{*}$ & .70 & $\begin{array}{l}.4 * \\
4\end{array}$ & 1 & & & & \\
\hline $\begin{array}{l}\text { 11. MCS } \\
\text { male }\end{array}$ & -.23 & -.20 & -.25 & -.07 & $.32 *$ & $\begin{array}{l}- \\
.03\end{array}$ & $\overline{3}_{38} *$ & -.21 & $\overline{-}_{55} *$ & $\begin{array}{l}-27 \\
1\end{array}$ & 1 & & & \\
\hline $\begin{array}{l}\text { 12. MCS } \\
\text { female }\end{array}$ & -.17 & $.42^{* *}$ & -.25 & $.34^{*}$ & $\begin{array}{l}- \\
.21\end{array}$ & $.48_{*}^{\bar{*}}$ & $.28 *$ & $\bar{x}^{5}{ }^{*}$ & $\overline{-}^{5} 2^{*}$ & $\overline{-}_{* 5} *$ & $\begin{array}{l}31 \\
31 \\
1\end{array}$ & 1 & & \\
\hline $\begin{array}{l}\text { 13. PCS } \\
\text { male }\end{array}$ & .12 & .06 & .00 & $\begin{array}{l}.2 \\
2\end{array}$ & $\begin{array}{l}.1 \\
8\end{array}$ & $\begin{array}{l}.2 \\
4\end{array}$ & $\begin{array}{l}.1 \\
5\end{array}$ & .27 & -.19 & .08 & .13 & $\begin{array}{r}- \\
.1 \\
4\end{array}$ & 1 & \\
\hline $\begin{array}{l}\text { 14. PCS } \\
\text { female }\end{array}$ & -.11 & $\overline{-}^{*} 1^{* *}$ & -.01 & $-\bar{x}^{*} 6^{*}$ & $\begin{array}{l}- \\
.03\end{array}$ & $.41_{*}^{*}$ & $\begin{array}{l}- \\
.00\end{array}$ & $-\overline{-}^{*}$ & -.05 & $.37^{*}$ & $\begin{array}{l}- \\
.26\end{array}$ & $\begin{array}{r}.1 \\
2\end{array}$ & - & 1 \\
\hline
\end{tabular}




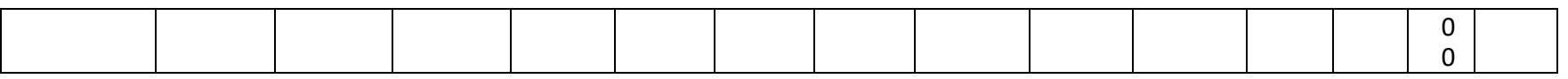

Note. $\mathrm{B} / \mathrm{C}=$ Behavior and communication; $\mathrm{PL}=$ Personal Life; $\mathrm{MCS}=$ Mental health component of the Rand 36 item Health Inventory Version 1.0; PCS = Physical health component of the Rand 36 item Health Inventory Version 1.0.

${ }^{*}$ Correlation is significant at the 0.05 level two-tailed. ${ }^{* *}$ Correlation is significant at the 0.01 level two-tailed.

\section{Question 1}

To identify if parenting stress was associated with mental and physical health, the most statistically significant stress subscales for female mental health (stress of personal and family life) and the most statistically significant stress subscale for female physical health (stress of caregiving), from the correlation table, were entered in a stepwise regression with the outcome variables female physical and mental component scores. The stress of caregiving was associated with female PCS $\left(R^{2}=.20, p<\right.$ $.001, B=-18)$ but not the MCS.

For males, only the stress of personal and family life subscale was associated with the MCS $\left(R^{2}=\right.$ $.29, p<.001, B=-.63)$. Only the stress of personal life subscale was associated with male PCS $\left(R^{2}=\right.$ $.07, p=.00)$.

\section{Question 2}

Next, we tested whether or not a wide discrepancy (D score) in expectations about family functioning (D score), was associated with lower mental and physical health component scores. Males and females were considered separately. A higher discrepancy score in family functioning (D score) was associated with both male and female mental health $(p<.001)$, accounting for $31 \%$ of the variance for females and $35 \%$ of the variance for males (see Table 4 ).

Table 4

Model of Male and Female PCS and MCS

\begin{tabular}{|c|c|c|c|c|c|}
\hline \multirow[b]{2}{*}{ Variables } & & \multicolumn{4}{|c|}{ Variables statistics } \\
\hline & & $B$ & $S E$ B & Standardized $B$ & $p$ \\
\hline \multicolumn{6}{|l|}{ Models for male parents } \\
\hline Model 1: Male PCS & $F(1,48)=11.05, p=.002$ & & & & \\
\hline Age & $R^{2}=.19$, adjusted $R^{2}=.17$ & -.49 & .15 & -.43 & .002 \\
\hline \multicolumn{6}{|l|}{ Model 2: Male MCS } \\
\hline Step 1 & $F(1,48)=27.34, p<.001$ & & & & \\
\hline Total male D score & $R^{2}=.36$, adjusted $R^{2}=.35$ & -.43 & .08 & -.60 & $<.001$ \\
\hline Step 2 & $F(2,47)=16.69, p<.001$ & & & & \\
\hline Total male D score & $R^{2}=.42$, adjusted $R^{2}=.39$ & -.43 & .08 & -.61 & $<.001$ \\
\hline Number of children live with fulltime & 3.481 .70 & .23 & .05 & & \\
\hline \multicolumn{6}{|l|}{ Models for female parents } \\
\hline \multicolumn{6}{|l|}{ Model 1: Female PCS } \\
\hline Stress parent care giving & $R^{2}=.20$, adjusted $R^{2}=.18$ & -.68 & .20 & -.45 & $<.001$ \\
\hline \multicolumn{6}{|l|}{ Model 2: Female MCS } \\
\hline Total female D score & $R^{2}=.32$, adjusted $R^{2}=.31$ & -.34 & .07 & -.57 & $<.001$ \\
\hline
\end{tabular}

\section{Table 4. Model of Male and Female PCS and MCS}

Variables statistics

\begin{tabular}{|c|c|c|c|c|}
\hline V & & $B$ & $S E$ & Standardized \\
a & & & $B$ & \\
r & & & & \\
i & & & & \\
a & & & \\
\hline
\end{tabular}




\begin{tabular}{|c|c|c|c|c|c|}
\hline $\begin{array}{l}\text { l } \\
\text { e } \\
\text { s }\end{array}$ & & & & & \\
\hline \multicolumn{6}{|l|}{ Models for male parents } \\
\hline Model 1: Male PCS & $\begin{array}{l}F(1,48)=11.05, p= \\
.002\end{array}$ & & & & \\
\hline Age & $\begin{array}{l}R^{2}=.19, \text { adjusted } R^{2} \\
=.17\end{array}$ & -.49 & .15 & -.43 & .002 \\
\hline \multicolumn{6}{|l|}{ Model 2: Male MCS } \\
\hline Step 1 & $\begin{array}{l}F(1,48)=27.34, p \\
<.001\end{array}$ & & & & \\
\hline Total male D score & $\begin{array}{l}R^{2}=.36, \text { adjusted } R^{2} \\
=.35\end{array}$ & -.43 & .08 & -.60 & $<.001$ \\
\hline Step 2 & $\begin{array}{l}F(2,47)=16.69, p \\
<.001\end{array}$ & & & & \\
\hline Total male D score & $\begin{array}{l}R^{2}=.42, \text { adjusted } R^{2} \\
=.39\end{array}$ & -.43 & .08 & -.61 & $<.001$ \\
\hline $\begin{array}{l}\text { Number of children live with } \\
\text { fulltime }\end{array}$ & 3.481 .70 & $\begin{array}{l}.2 \\
3 \\
\end{array}$ & .05 & & \\
\hline \multicolumn{6}{|l|}{$\begin{array}{l}\text { Models for female parents } \\
\text { Model 1: Female PCS }\end{array}$} \\
\hline Stress parent care giving & $\begin{array}{l}R^{2}=.20, \text { adjusted } R^{2} \\
=.18\end{array}$ & -.68 & .20 & -.45 & $<.001$ \\
\hline \multicolumn{6}{|l|}{ Model 2: Female MCS } \\
\hline Total female D score & $\begin{array}{l}R^{2}=.32, \text { adjusted } R^{2} \\
=.31\end{array}$ & -.34 & .07 & -.57 & $<.001$ \\
\hline
\end{tabular}

\section{Question 3}

Question 3 asked if discrepancy in expectations of family functioning mediates the relationship of stress (subscales) on mental (MCS) or physical health (PCS). Males and females were considered separately.

For males, only the stress of personal and family life subscale was associated with the discrepancy (D) score $\left(R^{2}=.33, p<.001, B=-.38\right)$ and the $\operatorname{MCS}\left(R^{2}=.29, p<.001, B=-.63\right)$. Only the stress of personal life subscale was associated with male PCS $\left(R^{2}=.07, p=.00\right)$, but there was no decrease in the effect on the PCS with the addition of the discrepancy (D) score. Therefore, the discrepancy (D) score mediated the effect of personal and family life stress on male mental health (MCS) but not physical health (PCS).

For females only the stress of caregiving predicted the female physical health (PCS). For female mental health, only the stress of personal and family life was associated with the female MCS. For females, the $D$ score mediated the effect of the stress of personal and family life $(p<.001)$ on MCS. While the stress of caregiving was a significant variable impacting physical health $(p<.001)$, the $D$ score did not mediate this effect (see Table 4).

We also entered demographics in the regression. For male parents, in Step 1 of the model (see Table 4) only the older age of the parent was associated with male physical health (PCS), accounting for $17 \%$ of the variance. In the second model, the number of children living at home and discrepancy score for "how much there is" - "how much there should be" family functioning accounted for $39 \%$ of the variance in male mental health (MCS). For female parents, in the first model, parental caregiving stress accounted for $18 \%$ of the variance for female physical health (PCS). In the second model, the discrepancy score for "how much there is" - "how much there should be" family functioning accounted 
for $31 \%$ of the variance in female mental health (MCS). In Model 2, Step 2 the discrepancy score along with more children accounted for $39 \%$ of the variance in MCS.

\section{Hypothesis Testing}

Hypothesis A stated that parent perceptions between "what is" and "what should be" family functioning will be associated with lower HRQL (physical and mental health). The relationship was partially supported. Using Pearson's $r$, males' D scores correlated - $.55(p<.01)$ with their MCS, but did not correlate significantly with PCS. Females' D scores correlated $-.58(p<.01)$ with their MCS and -.37 $(p<.01)$ with PCS.

Hypothesis B stated that mothers will have significantly greater discrepancy scores in family functioning than fathers. The results supported hypothesis B. For the FFFS there was a significant difference $(z=-3.12, p=002)$ for the discrepancy scores on the FFFS comparing males and females.

\section{Additional Female Models}

Additional females models of PCS (see Table 5) and MCS (see Tables 6and $\underline{7}$ ), were developed with variables that were significantly correlated with the outcome variable (PCS or MCS). We used regression to see which variables were significantly related once the other variables were considered. Because of the high intercorrelation of variables we noted that we had homoscedascity with for example coefficients of the parenting stress subscales alternating in sign when we simply entered all variables. Therefore, we used backward and stepwise regression with an entry criteria for a variable of $p<.05$ and a removal criterion of 0.1 to find what was associated with the outcomes. Table $\underline{5}$ and $\underline{6}$ displays the results of the amount of variance explained by each variable.

Table 5

Model of Female PCS of the SF-36 (Version 1.0)

\begin{tabular}{|c|c|c|c|c|c|c|c|}
\hline & \multicolumn{2}{|c|}{$\begin{array}{l}\text { Unstandardized } \\
\text { coefficients }\end{array}$} & \multicolumn{2}{|c|}{$\begin{array}{l}\text { Standardized } \\
\text { coefficients }\end{array}$} & \multirow[b]{2}{*}{ Sig. } & \multicolumn{2}{|c|}{$\begin{array}{l}95.0 \% \text { Confidence interval } \\
\text { for B }\end{array}$} \\
\hline & B & $S E$ & Beta & $t$ & & Lower bound & Upper bound \\
\hline \multicolumn{8}{|l|}{1} \\
\hline$($ Constant) $F(7,51)=1.808, p=.11$ & 61.827 & 9.818 & & 6.297 & .000 & 42.040 & 81.613 \\
\hline Child gender $R^{2}=.223$, Adjusted $R^{2}=.10$ & 4.722 & 4.348 & .150 & 1.086 & .283 & -4.041 & 13.486 \\
\hline Child age at diagnosis & -.963 & .788 & -.212 & -1.222 & .228 & -2.552 & .626 \\
\hline Number of children full or part time & -.566 & 1.850 & -.043 & -.306 & .761 & -4.294 & 3.163 \\
\hline Length in years of relationship & -.079 & .334 & -.042 & -.237 & .814 & -.752 & .594 \\
\hline Stress parent caregiving & -.609 & .201 & -.428 & -3.028 & .004 & -1.014 & -.204 \\
\hline Child age & .426 & .662 & .129 & .644 & .523 & -.908 & 1.761 \\
\hline Child diagnosis & -4.746 & 3.137 & -.217 & -1.513 & .137 & -11.069 & 1.576 \\
\hline
\end{tabular}

Table 5. Model of Female PCS of the SF-36 (Version 1.0)

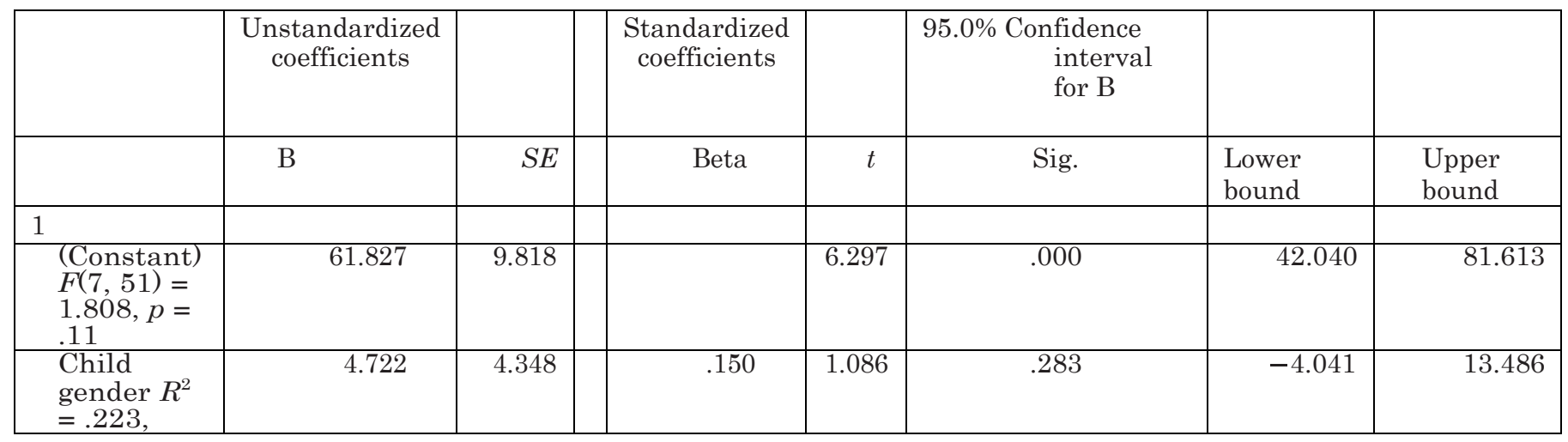




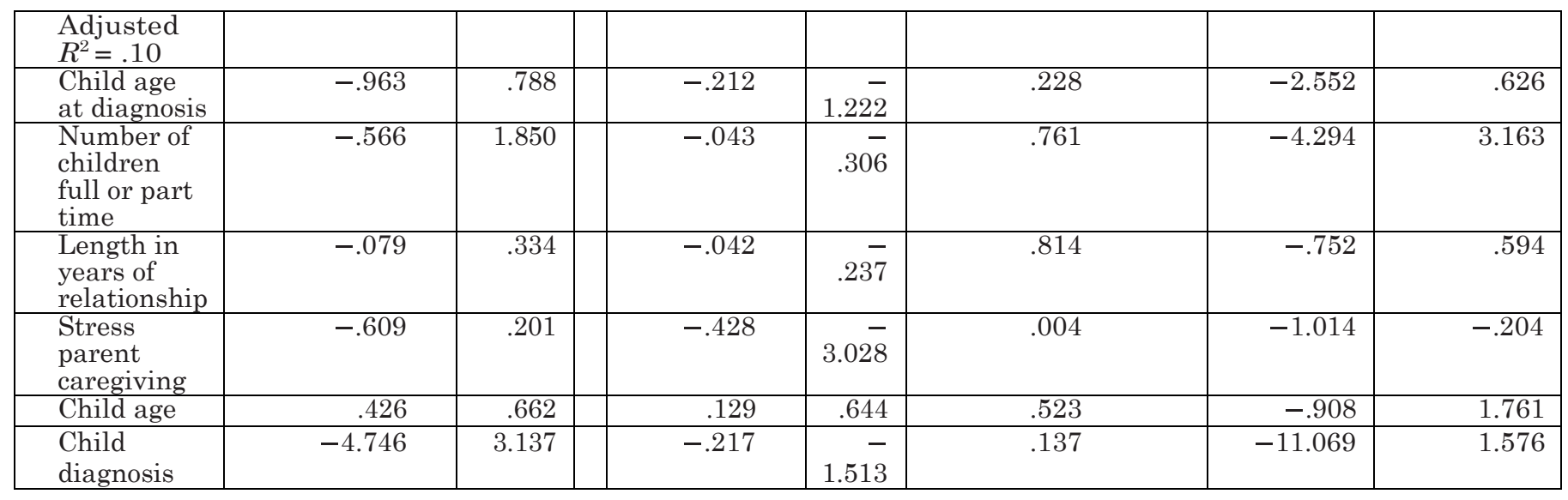

Table 6

Model of Female Mental Health Component Score (MCS) of the SF-36 (Version 1.0)

\begin{tabular}{|c|c|c|c|c|c|c|c|}
\hline \multirow[b]{2}{*}{ Variables model statistics } & \multicolumn{2}{|c|}{$\begin{array}{l}\text { Unstandardized } \\
\text { coefficients }\end{array}$} & \multirow{2}{*}{$\begin{array}{c}\begin{array}{c}\text { Standardized } \\
\text { coefficients }\end{array} \\
\text { Beta }\end{array}$} & \multirow[b]{2}{*}{$t$} & \multirow[b]{2}{*}{ sign. } & \multicolumn{2}{|c|}{$\begin{array}{l}95.0 \% \text { Confidence interval } \\
\text { for B }\end{array}$} \\
\hline & $B$ & $S E$ & & & & Lower bound & Upper bound \\
\hline \multicolumn{8}{|l|}{1} \\
\hline (Constant) & 37.763 & 10.868 & & 3.475 & .001 & 15.832 & 59.695 \\
\hline $\begin{array}{l}\text { Child gender } F(9,51)=3.611, p=.002 \\
\text { Child age diagnosed with ASD } R^{2}=.436,\end{array}$ & .170 & 5.181 & .004 & .033 & .974 & -10.287 & 10.626 \\
\hline adjusted $R^{2}=.315$ & -.802 & .915 & -.144 & -.877 & .386 & -2.648 & 1.044 \\
\hline Number of children full-time or part-time & .845 & 2.031 & .051 & .416 & .679 & -3.253 & 4.943 \\
\hline Length in years of relationship & -.061 & .364 & -.026 & -.168 & .867 & -.797 & .674 \\
\hline Child age & 1.492 & .761 & .367 & 1.960 & .057 & -.045 & 3.029 \\
\hline Diagnosis & 2.545 & 3.501 & .094 & .727 & .471 & -4.520 & 9.611 \\
\hline Stress: personal life subscale & -.143 & .216 & -.119 & -.661 & .512 & -.579 & .294 \\
\hline Total female D score & -.262 & 127 & -.392 & -2.065 & .045 & -.517 & -.006 \\
\hline Total male D score & .018 & .110 & .024 & . 163 & .871 & -.203 & .239 \\
\hline
\end{tabular}

Table 6. Model of Female Mental Health Component Score (MCS) of the SF-36 (Version 1.0)

\begin{tabular}{|c|c|c|c|c|c|c|c|c|}
\hline & & $\begin{array}{l}\text { Unstandardize } \\
\text { d coefficients }\end{array}$ & & $\begin{array}{l}\text { Standardized } \\
\text { coefficients }\end{array}$ & & & $\begin{array}{c}\text { 95.0\% Confidence } \\
\text { interval } \\
\text { for B }\end{array}$ & \\
\hline & $\begin{array}{l}\text { Variables } \\
\text { model } \\
\text { statistics }\end{array}$ & $B$ & $\begin{array}{l}S \\
E\end{array}$ & Beta & $t$ & $\begin{array}{l}\operatorname{sign} \\
.\end{array}$ & Lower bound & $\begin{array}{l}\text { Upper } \\
\text { bound }\end{array}$ \\
\hline \multicolumn{9}{|l|}{1} \\
\hline & (Constant) & 37.763 & 10.868 & & 3.475 & .001 & 15.832 & $\begin{array}{l}59.69 \\
5\end{array}$ \\
\hline & $\begin{array}{l}\text { Child } \\
\text { gender } \\
F(9,51)= \\
3.611, p= \\
.002\end{array}$ & .170 & 5.181 & $\begin{array}{l}.00 \\
4\end{array}$ & .033 & .974 & -10.287 & $\begin{array}{l}10.62 \\
6\end{array}$ \\
\hline & $\begin{array}{l}\text { Child age } \\
\text { diagnosed } \\
\text { with ASD } \\
R^{2}=.436\end{array}$ & & & & & & & \\
\hline & $\begin{array}{l}\text { adjusted } \\
R^{2}=.315\end{array}$ & -.802 & .915 & $-\overline{144}$ &.$\overline{8}$ & .386 & -2.648 & $\begin{array}{l}1.04 \\
4\end{array}$ \\
\hline & $\begin{array}{l}\text { Number of } \\
\text { children } \\
\text { full-time or } \\
\text { part-time }\end{array}$ & .845 & 2.031 & .05 & .416 & .679 & -3.253 & $\begin{array}{l}4.94 \\
3\end{array}$ \\
\hline & $\begin{array}{l}\text { Length in } \\
\text { years of }\end{array}$ & -.061 & .364 & .026 &.$\overline{168}$ & .867 & -.797 & $\begin{array}{l}.67 \\
4 \\
\end{array}$ \\
\hline
\end{tabular}




\begin{tabular}{|c|c|c|c|c|c|c|c|}
\hline $\begin{array}{l}\text { relationshi } \\
\mathrm{p}\end{array}$ & & & & & & & \\
\hline Child age & 1.492 & .761 & $\begin{array}{l}.36 \\
7\end{array}$ & 1.960 & .057 & -.045 & $\begin{array}{l}3.02 \\
9\end{array}$ \\
\hline Diagnosis & 2.545 & 3.501 & $\begin{array}{l}.09 \\
4\end{array}$ & .727 & .471 & -4.520 & $\begin{array}{l}9.61 \\
1\end{array}$ \\
\hline $\begin{array}{l}\text { Stress: } \\
\text { personal } \\
\text { life } \\
\text { subscale }\end{array}$ & -.143 & .216 & $\overline{.119}$ &.$\overline{-}$ & .512 & -.579 & $\begin{array}{l}.29 \\
4\end{array}$ \\
\hline $\begin{array}{l}\text { Total } \\
\text { female D } \\
\text { score }\end{array}$ & -.262 & .127 & $\begin{array}{l}- \\
.392\end{array}$ & $\begin{array}{r}-\overline{-} \\
2.06 \\
5\end{array}$ & .045 & -.517 & $\overline{.006}$ \\
\hline $\begin{array}{l}\text { Total male } \\
\text { D score }\end{array}$ & .018 & .110 & $\begin{array}{l}.02 \\
4 \\
\end{array}$ & .163 & .871 & -.203 & $\begin{array}{l}.23 \\
9 \\
\end{array}$ \\
\hline
\end{tabular}

Table 7

Model of Female Mental Health Component Score (MCS) of SF-36 (Versions 1.0)

\begin{tabular}{|c|c|c|c|c|c|c|c|}
\hline \multirow[b]{2}{*}{ Variables model statistics } & \multicolumn{2}{|c|}{$\begin{array}{c}\text { Unstandardized } \\
\text { coefficients }\end{array}$} & \multirow{2}{*}{$\begin{array}{c}\begin{array}{c}\text { Standardized } \\
\text { coefficients }\end{array} \\
\text { Beta }\end{array}$} & \multirow[b]{2}{*}{$t$} & \multirow[b]{2}{*}{ Sig. } & \multicolumn{2}{|c|}{$\begin{array}{l}95.0 \% \text { Confidence interval } \\
\text { for B }\end{array}$} \\
\hline & $\mathrm{B}$ & $S E$ & & & & Lower bound & Upper bound \\
\hline \multicolumn{8}{|l|}{1} \\
\hline$($ Constant $) F(12,48)=2.45, p=.019$ & 30.071 & 12.994 & & 2.314 & .026 & 3.718 & 56.425 \\
\hline Child gender $R^{2}=.45$, Adjusted $R^{2}=.266$ & 2.472 & 5.771 & .062 & .428 & .671 & -9.233 & 14.177 \\
\hline Child age diagnosis & -.841 & 1.040 & -.155 & -.809 & .424 & -2.950 & 1.268 \\
\hline Number of children full/part-time & -.229 & 2.314 & -.014 & -.099 & .922 & -4.923 & 4.464 \\
\hline Length of relationship & .044 & .409 & .019 & .107 & .915 & -.785 & .872 \\
\hline Stress care giving & -.430 & .371 & -.241 & -1.160 & .254 & -1.182 & .322 \\
\hline Stress personal life & -.032 & .269 & -.027 & -.119 & .906 & -.577 & .514 \\
\hline Stress advocating needs & .289 & .677 & .090 & .427 & .672 & -1.084 & 1.663 \\
\hline Stress behavior and communication & .427 & .529 & .166 & .806 & .425 & -.646 & 1.499 \\
\hline Child age & 1.372 & .818 & .351 & 1.677 & .102 & -.287 & 3.032 \\
\hline Total male D score & .015 & .121 & .021 & .125 & .901 & -.230 & .260 \\
\hline Total female D score & -.313 & .146 & -.484 & -2.147 & .039 & -.608 & -.017 \\
\hline Diagnosis & 1.350 & 3.803 & .050 & .355 & .725 & -6.363 & 9.064 \\
\hline
\end{tabular}

Table 7. Model of Female Mental Health Component Score (MCS) of SF-36 (Versions 1.0)

\begin{tabular}{|c|c|c|c|c|c|c|c|c|}
\hline & & $\begin{array}{l}\text { Unstandardize } \\
\text { d } \\
\text { coefficients }\end{array}$ & & $\begin{array}{l}\text { Standardize } \\
\mathrm{d} \\
\text { coefficients }\end{array}$ & & & $\begin{array}{c}95.0 \% \text { Confidence } \\
\text { interval } \\
\text { for B }\end{array}$ & \\
\hline & $\begin{array}{l}\text { Variabl } \\
\text { es } \\
\text { model } \\
\text { statistic } \\
\text { s }\end{array}$ & B & $\begin{array}{l}S \\
E\end{array}$ & Beta & $t$ & Sig & Lower bound & $\begin{array}{l}\text { Upper } \\
\text { bound }\end{array}$ \\
\hline \multicolumn{9}{|c|}{ 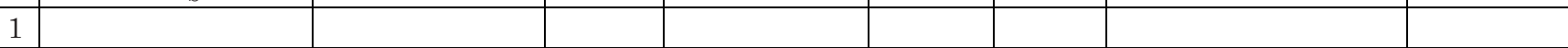 } \\
\hline & $\begin{array}{l}\text { (Constant) } \\
F(12,48)= \\
2.45, p=.019\end{array}$ & 30.071 & 12.994 & & $\begin{array}{r}2.31 \\
4\end{array}$ & $\begin{array}{l}.02 \\
6\end{array}$ & 3.718 & $\begin{array}{l}56.42 \\
5\end{array}$ \\
\hline & $\begin{array}{l}\text { Child gender } R^{2} \\
=.45, \text { Adjusted } \\
R^{2}=.266\end{array}$ & 2.472 & 5.771 & $\begin{array}{l}.06 \\
2\end{array}$ & .428 & $\begin{array}{l}.67 \\
1\end{array}$ & -9.233 & $\begin{array}{l}14.17 \\
7\end{array}$ \\
\hline & $\begin{array}{l}\text { Child age } \\
\text { diagnosis }\end{array}$ & -.841 & 1.040 & $\overline{.155}$ & $.8 \overline{9}$ & $\begin{array}{l}.42 \\
4\end{array}$ & -2.950 & $\begin{array}{l}1.26 \\
8\end{array}$ \\
\hline & $\begin{array}{l}\text { Number of } \\
\text { children } \\
\text { full/part-time }\end{array}$ & -.229 & 2.314 & .014 & $.0 \overline{9}$ & $\begin{array}{l}.92 \\
2\end{array}$ & -4.923 & $\begin{array}{l}4.46 \\
4\end{array}$ \\
\hline & $\begin{array}{l}\text { Length of } \\
\text { relationship }\end{array}$ & .044 & .409 & $\begin{array}{l}.01 \\
9\end{array}$ & .107 & $\begin{array}{l}.91 \\
5\end{array}$ & -.785 & $\begin{array}{l}.87 \\
2\end{array}$ \\
\hline & $\begin{array}{l}\text { Stress care } \\
\text { giving }\end{array}$ & -.430 & .371 & .241 & $\begin{array}{r}-\overline{16} \\
0\end{array}$ & $\begin{array}{l}.25 \\
4\end{array}$ & -1.182 & $\begin{array}{l}.32 \\
2\end{array}$ \\
\hline & $\begin{array}{l}\text { Stress personal } \\
\text { life }\end{array}$ & -.032 & .269 & .027 & $.1 \overline{19}$ & $\begin{array}{l}.90 \\
6 \\
\end{array}$ & -.577 & $\begin{array}{l}.51 \\
4 \\
\end{array}$ \\
\hline & $\begin{array}{l}\text { Stress } \\
\text { advocating needs }\end{array}$ & .289 & .677 & $\begin{array}{l}.09 \\
0\end{array}$ & .427 & $\begin{array}{l}.67 \\
2\end{array}$ & -1.084 & $\begin{array}{l}1.66 \\
3\end{array}$ \\
\hline
\end{tabular}




\begin{tabular}{|c|c|c|c|c|c|c|c|}
\hline $\begin{array}{l}\text { Stress behavior } \\
\text { and } \\
\text { communication }\end{array}$ & .427 & .529 & $\begin{array}{l}.16 \\
6\end{array}$ & .806 & .42 & -.646 & $\begin{array}{l}1.49 \\
9\end{array}$ \\
\hline Child age & 1.372 & .818 & $\begin{array}{l}.35 \\
1\end{array}$ & $\begin{array}{r}1.67 \\
7\end{array}$ & $\begin{array}{l}.10 \\
2\end{array}$ & -.287 & $\begin{array}{l}3.03 \\
2\end{array}$ \\
\hline $\begin{array}{l}\text { Total male D } \\
\text { score }\end{array}$ & .015 & .121 & $\begin{array}{l}.02 \\
1\end{array}$ & .125 & $\begin{array}{l}.90 \\
1\end{array}$ & -.230 & $\begin{array}{l}.26 \\
0\end{array}$ \\
\hline $\begin{array}{l}\text { Total female D } \\
\text { score }\end{array}$ & -.313 & .146 & $-\overline{4} 84$ & $\begin{array}{r}-\overline{14} \\
\end{array}$ & $\begin{array}{l}.03 \\
9\end{array}$ & -.608 & $\overline{.}_{.017}$ \\
\hline Diagnosis & 1.350 & 3.803 & $\begin{array}{l}.05 \\
0\end{array}$ & .355 & $\begin{array}{l}.72 \\
5\end{array}$ & -6.363 & $\begin{array}{l}9.06 \\
4\end{array}$ \\
\hline
\end{tabular}

\section{DISCUSSION}

Findings for parenting stress totals on the PSS:A included somewhat to moderate amounts of parenting stress, with a total scale mean of $71.18(S D=25.7)$ for the male and female parents. These means are similar to the total scale mean for a female sample reported by Phetrasuwan (2003)of 75.01 (SD = 22.65). The large standard deviations suggest that the data may be bimodal or multimodal. Future analysis could be done to assess for this phenomenon. The Easter Seals (2009) study reported that a primarily female sample was stressed by financial concerns for their ASD-affected child. Financial concerns are captured in the personal/family life subscale of the PSS:A. That subscale was the only stress subscale that was associated with poor male and female mental health in the present study. Both male and female parents perceived that dealing with the personal and family life was the most stressful, and the personal and life issues stress was associated with poorer mental health outcomes. Past researchers reported parents perceived they were most stressed by their child's behaviors ( $\underline{C l a r k}_{2}$

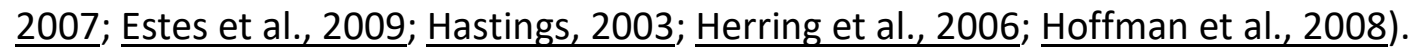

In the present study, measuring stress with the PSS:A, which has a personal and family life stress subscale advances the state of the state of the science on understanding stressors associated with mental health in this population. Parents would benefit from a discussion focused on planning how to deal the personal and family life stressors captured in the subscale of the PSS:A such as differences in opinions, how to balance the needs of other family members and work responsibilities, and managing finances.

For family functioning, females in the present study had a wider range for discrepancy scores than males. In addition, male D score and female D scores were positively related. When males had a wide discrepancy between expectations and perceived functioning, the females also had a wide discrepancy in expectations. A difference in what was valued could account for the difference. Past research notes that males tend to value financial contributions and females value emotional support (Deris, 2005).

Males and females differed in their expectations for supportive family functioning. The total mean discrepancy score for the FFFS (see Table 1) was 33.06 for men and 41.97 for women. The discrepancy scores for men match findings of past studies. Feetham et al. (2007) reported that discrepancy scores tend to range from 17-35. The females' scores were higher than the norm indicating that women caring for a child with ASD are not getting what they expect from supportive family functioning.

In the present study HRQL was measured by the Rand 36-Item Health Survey 1.0, which allowed for two components (MCS and PCS) (Table 1and 2). The physical health scores for both men and women were close to the reported average of 50 (Ware et al., 1994). Conversely, the MCS scores were much 
lower than the expected norm of 50 (Ware et al., 1994). Females (MCS = 34.21 \pm 13.11 ) had lower scores than males (MCS $=41.60 \pm 12.93$ ). Past studies with mostly female participants have also found psychological distress in parents of children with ASD (Allik, 2006; Phetrasuwan, 2003). Score comparisons for parents of children with ASD to other studies were not possible because of the use of different measures; Lee et al. (2009) used the MOS 36-Item Short Form Survey (Ware \& Sherbourne, 1992); Allik et al. (2006) used the SF-12 (Ware, Kosinski, \& Keller, 1996).

\section{Question 1}

The stress of caregiving was associated with female physical health but not the mental health. Previous studies found parents of children with ASD were more stressed than other parents (Brobst et al., 2009; Herring et al., 2006; Konstantareas \& Papageorgiou, 2006) with mothers perceiving more stress than fathers (Herring et al., 2006; Little, 2002). However, the stress of caregiving was associated with lower female physical health, accounting for $18 \%$ of the variance. The stress of caregiving subscale of the PSS:A includes managing sleep problems, bathing, and dressing difficulties, which are physically draining for female parents. The physical work of caregiving impacts women most likely because they are often the main caregiver (Little, 2002).

For males, only the stress of personal and family life subscale was associated with the mental and physical health MCS. Items on this scale include financial problems, and finding time for their own activities. Male parents are the traditional wage-earner in the family (Easter Seals, 2009). Often mothers of children with ASD manage care of the child at home. Male parents may not be able to find time to exercise and that may impact their physical health.

\section{Question 2}

Higher discrepancy scores for family functioning were related to lower mental health for both males and females. This finding extends to male parents the results of previous studies (Dunn et al., 2001; Hastings et al., 2005) that found a discrepancy in expectations negatively affects both mental and physical health for females. As the discrepancy in how much there is and how much there should be for the FFFS rose, so too did parenting stress. Knafl and Deatrick (2003) found joint effort to manage illness with different views on how to manage the situation can affect family functioning. Although the parents work together they may have different future expectations or a plan on how to get there, which is a potential source of distress.

\section{Question 3}

For males, only the stress of personal and family life subscale was associated with the discrepancy (D) score and mental health. Only the stress of personal life subscale was associated with male PCS, but there was no decrease in the effect on the PCS with the addition of the discrepancy (D) score.

Therefore the discrepancy (D) score mediated the effect of personal and family life stress on male mental health (MCS) but not physical health (PCS). Additional analysis of demographic variables found that the older age of the father was associated with male PCS.

For females the only the stress of caregiving predicted the female physical health (PCS). For female mental health, only the stress of personal and family life was associated with the female MCS. For females, the $D$ score mediated the effect of the stress of personal and family life on mental health. While the stress of caregiving was a significant variable impacting physical health the D score did not 
mediate this effect. The findings support the two theories that framed the study. In the present study, the social network is conceptualized as the male-female partners' expectations about supportive family functioning (that may include members from a network outside the immediate family) that are thought to mediate stress. Networks also have a positive impact on parental health according to this model. Without the supportive family functioning, both males and females are at risk for poorer mental health.

The findings in the present study are also consistent with past research where support is conceptualized as a result of a social process. Mothers with psychological distress perceived low social relationship support in past studies with parents of children with ASD (Bromley et al., 2004; Tobing \& Glenwick, 2006) and had children with problem behaviors (Allik et al., 2006).

\section{Hypotheses Testing}

Hypothesis A was partially supported. Parent perceptions between "what is" and "what should be" family functioning were correlated mental health and female health for females and mental health only for males. Hypothesis B, was supported as mothers had a significantly greater discrepancy scores in family functioning than fathers. Because mothers had the wider discrepancy in expectations, and the discrepancy was correlated to both mental and physical health in mothers, additional female models were developed.

\section{Additional Female Models}

Additional females models of PCS and MCS showed that the stress of caregiving was associated with female physical health (see Table 5) and the female D score was associated with mental health (see Tables 6 and 7). In past studies parents reported receiving little support from extended family members (Easter Seals, 2009). Within the family, division of labor was reported as being the most common contributor to marital conflict (IAN, 2009).

\section{Limitations}

There are admitted limitations in the study that include a one-time data collection and not confirming the diagnosis of ASD. Lack of verification that both parents completed questionnaires separately is also a potential weakness. ASD tends to be diagnosed in children of well-educated parents (Meter et al., 2010). Mulvihill et al. (2009) report that the race and ethnicity distribution in Wisconsin is $65.7 \%$ White, nonhispanic; $18.1 \%$ Black, non-Hispanic; $12.2 \%$ Hispanic, and 4\% Other. Therefore, the recruited sample of parents in the present study is congruent with a population with high diagnostic incidence. The recruitment strategy was a strength in accessing those with a diagnosis, although there are thought to be many children of other races and ethnicities with characteristics of ASD. In the present study, fathers and mothers of children with ASD participated. The literature review highlighted the historic challenge of recruiting fathers of children with ASD and other health conditions in research studies. Placing flyers on the Internet at sites and in clinics that parents of children with ASD were likely to access, worked well in the present study. As the SF 36 proved cumbersome to use as an outcome measure, the SF-12 is recommended for future research. Dyadic analysis is recommended as a basis for interventions with dyads (Knafl et al., 2009; Knafl, Knafl, \& McCorkle, 2005). A manuscript on this is in progress (Johnson, Feetham, Knafl, \& Simpson, 2011). 


\section{Clinical Applications}

The main finding of the study was that there were significant differences in expectations between parents related to supportive family functioning. The discrepancy between expectations about supportive family functioning was associated with poor mental health for parents. Wider discrepancy in expectations about supportive family functioning was also associated with parenting stress.

The significant difference in expectations suggests needs that must be addressed by clinicians. It may be useful for clinicians to facilitate a conversation between parents to allow parents time to discuss and understand their expectations. Once the expectations are understood it may be possible for parents to reach consensus on alternate ways to make decisions and provide care for their child. Possible approaches include: (1) assess mothers' and fathers' expectations, then foster discussion about areas of similarity and difference; (2) affirm the normality of different expectations; (3) encourage consideration of alternate ways expectations could be met and discussion of different expectations; and (4) foster problem-solving and resource identification. Families may need more external support to help (particularly) mothers have better mental and physical functioning in addition to the focus on internal family dynamics and relationships.

More children living full with the parents, indicating possible extra sibling stress and financial burdens, were also associated with poor male mental health. Females had lower PCS and MCS scores than males, and higher stress scores on all the stress subscales than the males. The amount of variance that the discrepancy score accounts for is large. Interventions addressing the discrepancy in expectations are likely to contribute to improved mental health for parents.

\section{CONCLUSIONS}

In conclusion, the findings of the study guide health care professionals in their assessment and intervention planning related to parenting stress, family functioning, and physical and mental health for parents of children with ASD. While past studies highlight behavior problems of the child with ASD as stressful, the stress of personal and family life (finances, work responsibilities, balancing the needs of siblings) and the discrepancy in expectations related to family functioning were negatively associated with parents' mental health. Furthermore, the discrepancy in expectations mediated the mental health in both parents. We know that family functioning is a process amenable to change. Health care professionals should encourage family members to reflect on their different expectations. Central to a family assessment for quality health care is knowing the structure of a family and knowing what family functions are being met and who is assisting the meeting of the functions (Feetham, 2005). The reflection affords the family an opportunity to negotiate the unmet expectations.

Females' physical health was impacted by the physical tasks related to caring for children, which becomes more physically demanding as a child ages. Future research should look at the amount of time spent with the child and the age of the child: both may increase stress as the child and family age.

New research should relate to the current state of the science. Gender differences were reported, but the amount of time spent with the child was not reported. Future research could assess if differences were a result of mothers spending more time with and having more responsibility for the child. Effective strategies to recruit and retain fathers or male partners are also needed. The expectation that 
even parents of the same child may well have different experiences and views could also be opened up for discussion and thereby normalized with parents of children with ASD.

\section{REFERENCES}

Abidin, R. (1995). Parenting Stress Index: Professional manual. Odessa, FL: Psychological Assessment Resources.

AHRQ. (2009). Research Reviews: Comparative effectiveness of therapies for children with Autism Spectrum Disorders. U.S. Department of Health and Human Services Agency for Healthcare Research and Quality, Retrieved from http://effectivehealthcare.ahrq.gov/healthInfo.cfm?infotype=rr\&processID=106\&status=d

Allik, H., Larsson, J.-O., \& Smedje, H. (2006). Health-related quality of life in parents of school-age children with Asperger Syndrome or High-Functioning Autism. Health \& Quality of Life Outcomes, 4, 1. doi:10.1186/1477-7525-4-1

Altiere, M. J., \& Von Kluge, S. (2009). Family functioning and coping behaviors in parents of children with autism. Journal of Child and Family Studies, 18, 83-92. doi:10.1007/s10826-008-9209-y

American Psychiatric Association. (2000). Diagnostic and statistical manual of mental disorders (4th edition ed. TR). Washington, DC: American Psychiatric Association.

Andrews, M. P., Bubolz, M., \& Paolucci, B. (1980). An ecological approach to study of the family. Marriage and Family Review, 31, 29-49.

Baker, B. L., Blacher, J., \& Olsson, M. (2005). Preschool children with and without developmental delay: Behaviour problems, parents' optimism and well-being. Journal of Intellectual Disability Research, 49, 575-590. doi:10.1111/j.1365-2788.2005.00691.x

Baron, R. M., \& Kenny, D. A. (1986). The moderator-mediator variable distinction in social psychological research: Conceptual, strategic and statistical considerations. Journal of Personality and Social Psychology, 51, 1173-1182. doi:10.1037/0022-3514.51.6.1173

Brobst, J., Clopton, J., \& Hendrick, S. (2009). Parenting children with Autism Spectrum Disorders: The couple's relationship. Focus on Autism and Other Developmental Disabilities, 24, 38-49. doi:10.1177/1088357608323699

Bromley, J., Hare, D. J., Davison, K., \& Emerson, E. (2004). Mothers supporting children with autistic spectrum disorders: Social support, mental health status and satisfaction with services. Autism, 8, 409-423. doi:10.1177/1362361304047224

Cassano, M., Adrian, M., Veirs, G., \& Zaman, J. (2006). The Inclusion of fathers in empirical investigation of child psychopathology: An update. Journal of Clinical Child and Adolescent Psychology, 35, 583-589. doi:10.1207/s15374424jccp3504_10

Clark, T. A. (2007). Mediation of parents stress through parent attribution and self-efficacy: Implications for the parents of children with Autism Spectrum Disorders. Unpublished Dissertation, University of Kentucky, Lexington, KY.

Cohen, S., \& McKay, G. (1984). Social support, stress, and the buffering hypothesis: A Theoretical analysis. In A.Baum, S. E.Taylor, \& J. E.Singer (Eds.), Handbook of psychology and health (Vol. 4, pp. 253-267). Hillsdale, NJ: Erlbaum.

Cutrona, C. E., \& Russell, D. W. (1990). Type of social support and specific stress: Toward a theory of optimal matching. In B. R.Sarason, I. G.Sarason, \& G.Pierce (Eds.), Social support: An interactional view (pp. 319-336). New York, NY: Wiley. 
Deris, A. R. (2005). Social supports among parents of children recently diagnosed with autism: Comparisons between mothers and fathers. Unpublished Dissertation, University of New Orleans, New Orleans, LA.

Donenberg, G., \& Baker, B. L. (1993). The impact of young children with externalizing behaviors on their families. Journal of Abnormal Child Psychology, 21, 179-198.

Dunn, M. E., Burbine, T., Bowers, C. A., \& Tantleff-Dunn, S. (2001). Moderators of stress in parents of children with autism. Community Mental Health Journal [NLM-MEDLINE], 37, 39.

Easter Seals. (2009). Easter Seals' living with autism study. Retrieved from http://www.easterseals.com/site/PageServer?pagename=ntlc8 living with autism study home

Estes, A., Munson, J., Dawson, G., Koehler, E., Zhou, X., \& Abbott, R. (2009). Parenting stress and psychological functioning among mothers of preschool children with autism and developmental delay. Autism, 13, 375-387. doi:10.1177/1362361309105658

Feetham, S. L. (2005). Family nursing: Challenges and opportunities: Providing leadership in family nursing from local to global health. Journal of Family Nursing, 11, 327-331. doi:10.1177/1074840705280820

Feetham, S. (2011). The relationship of family to health: Historical overview. In M. C.Rosenberg (Ed.), Encyclopedia of family health (pp. xxxi-xxxvi). London: Sage Publications.

Feetham, S., \& Humenick, S. (1982). The Feetham Family Functioning Survey. In S. Humenick (Ed.), Analysis of current assessment strategies in the health care of young children and childbearing families (pp. 259-268). New York, NY: Appleton-Century Crofts.

Ferrans, C. E., Zerwic, J., Wilbur, J., \& Larson, J. (2005). Conceptual model of health-related quality of life. Journal of Nursing Scholarship, 37, 336-342. doi:10.1111/j.1547-5069.2005.00058.x

Friedman, M., Bowden, V. R., \& Jones, E. G. (2003). Family nursing: Research, theory, and practice (5th ed.). Upper Saddle River, NJ: Prentice Hall.

Friedrich, W. N., Greenberg, M. T., \& Crnic, K. (1983). A Short Form of the Questionnaire on Resources and Stress. American Journal of Mental Deficiency, 88, 41-48.

Hastings, R. P. (2003). Child behaviour problems and partner mental health as correlates of stress in mothers and fathers of children with autism. Journal of Intellectual Disability Research, 47, 231237. doi:10.1046/j.1365-2788.2003.00485.x

Hastings, R., Kovshoff, H., Brown, T., Ward, N., Espinosa, F., \& Remington, B. (2005). Coping strategies in mothers and fathers of preschool and school-age children with autism. Autism, 9, 377-391. doi:10.1177/1362361305056078

Hastings, R. P., \& Johnson, E. (2001). Stress in UK families conducting intensive home-based behavioral intervention for their young child with autism. Journal of Autism and Developmental Disorders, 31, 327-336. doi:10.1023/A:1010799320795

Herring, S., Gray, J., Taffe, B., Sweeny, D., \& Einfeld, S. (2006). Behaviour and emotional problems in toddlers with pervasive developmental disorders and developmental delay: Associations with parental mental health and family functioning. Journal of Intellectual Disability Research, 50, 874-882. doi:10.1111/j.1365-2788.2006.00904.x

Hoffman, C., Sweeney, D., Lopez-Wagner, M., Hodge, D., Nam, C., \& Botts, B. (2008). Children with Autism: Sleep problems and mother's stress. Focus on Autism and Other Developmental Disabilities, 23, 155-165. doi:10.1177/1088357608316271 
IAN. (2009). IAN Research report \#11. Family Stress-Part 3: Relationships and resilience. Retrieved from http://iancommunity.org/cs/ian research reports/ian research report sept 2009.

Johnson, N., Feetham, S., Knafl, G., \& Simpson, P. (2011). Health related quality of life for parents of children with Autism Spectrum Disorder: A dyadic analysis. Manuscript in process.

Kersh, J., Hedvat, T. T., Hauser-Cram, P., \& Warfield, M. E. (2006). The contribution of marital quality to the well-being of parents of children with developmental disabilities. Journal of Intellectual Disability Research, 50, 883-893. doi:10.1111/j.1365-2788.2006 .00906.x

Knafl, G. J., Dixon, J., O'Malley, J., Grey, M., Deatrick, J., Gallo, A., \& Knafl, K. A. (2009). Analysis of cross-sectional univariate measurements for family dyads using linear mixed modeling. Journal of Family Nursing, 15, 130-151. doi:10.1177/1074840709331641

Knafl, G., Knafl, K., \& McCorkle, R. (2005). Mixed models incorporating intra-familial correlation trough spatial autoregression. Research in Nursing \& Health, 28, 348-356. doi:10.1002/nur.20082

Knafl, K. A., \& Deatrick, J. A. (2003). Further refinement of the family management style framework. Journal of Family Nursing, 9, 232-256. doi:10.1177/1074840703255435

Konstantareas, M. M., \& Papageorgiou, V. (2006). Effects of temperament, symptom severity and level of functioning on maternal stress in Greek children and youth with ASD. Autism, 10, 593-607. doi:10.1177/1362361306068511

Lakey, B., \& Cohen, S. (2000). Social support theory and measurement. In S.Cohen, L.Underwood, \& B.Gottlieb (Eds.), Social support measurement and intervention (pp. 29-52). Oxford: Oxford University Press.

Lantos, J. D. (2007). The edge of the known world. Health Affairs, 26, 510-514.

Lazarus, R. S. (1999). Stress and emotion: A new synthesis. New York, NY: Springer Publishing Company. Lazarus, R. S., \& Folkman, S. (1984). Stress, appraisal, and coping. New York, NY: Springer Publishing Company Inc.

Lee, G. K., Lopata, C., Volker, M., Thomeer, M. L., Nida, R. E., Toomey, J. A., . . Smerbeck, A. M. (2009). Health related quality of life of parents of children with high functioning autism spectrum disorder. Focus on Autism and Other Disablities, 24, 227-239. doi:10.1177/1088357609347371

Little, L. (2002). Differences in stress and coping for mothers and fathers of children with Aspergers syndrome and mom-verbal learning disorders. Pediatric Nursing, 28, 565-570.

McCubbin, H., \& Thompson, A. (Eds.). (1991). Family assessment inventories for research and practice (2nd ed.). Madison, WI: University of Wisconsin.

Meltzer, H., Gatward, R., Goodman, R., \& Ford, T. (2000). Mental health of children and adolescents in Great Britain. London: Stationery Office.

Mulvihill, B., Wingate, M., Kirby, R. S., Pettygrove, S., Cunniff, C., Meaney, F. J., . . Ratchford, A. (2009). Prevalence of autism spectrum disorders: Autism and Developmental Disabilities Monitoring Network Surveillance Year 2006, Centers for Disease Control and Prevention (CDC). MMWR Surveillance Summary, 58, 1-20.

Olson, D., McCubbin, H., Barnes, H., Lansen, A., Muxen, H., \& Wilson, M. (1985). Family inventories. St. Paul, MN: University of Minnesota.

Phetrasuwan, S. (2003). Psychological adjustment in mothers of children with Autism Spectrum Disorder. Chapel Hill, NC: University of North Carolina, Chapel Hill. 
Phetrasuwan, S., \& Miles, M. S. (2009). Parenting stress in mothers of children with Autism Spectrum Disorder. Journal for Specialists in Pediatric Nursing, 14, 157-165. doi:10.1111/j.17446155.2009.00188.x

Randolph, I. (1977). The CES-D scale: A self report depression scale for research in the general population. Applied Psychological Measurement, 1, 385-401.

Rice, C. (2009). Prevalence of Autism Spectrum Disorders: Autism and Developmental Disabilities Monitoring Network, United States, 2006. CDC MMWR Surveillance Summaries, 58. Retrieved from http://www.cdc.gov/mmwr/preview/mmwrhtml/ss5810a1.htm

Roberts, C. S., \& Feetham, S. (1982). Assessing family functioning across three areas of relationships. Nursing Research, 31, 231-235. doi:10.1097/00006199-198207000-00011

Ryff, C. D., \& Keyes, A. (1995). The Structure of psychological well being revisited. Journal of Personality and Social Psychology, 69, 719-727. doi:10.1037/0022-3514.69.4.719

Sawin, K. J., \& Harrigan, M. P. (1995). Well-established self-report instruments: Feetham Family Functioning Survey (FFFS). In K. J.Sawin \& M. P.Harrigan (Eds.), Measuring family functioning for research and practice (pp. 42-49). New York, NY: Springer Publishing Company.

SPSS. (2008). Statistical software package for the social sciences 16.0. Chicago, IL: SPSS.

Tanguay, P. (2006). Autism and pervasive development disorder. In P.Jensen, P.Knapp, \& D.Mrazek (Eds.), Toward a new diagnostic system for child psychopathology (pp. 150-161). New York, NY: The Guilford Press.

Tobing, L., \& Glenwick, D. (2006). Predictors and moderators of psychological distress in mothers of children with pervasive developmental disorders. Journal of Family Social Work, 10, 1-22. doi:10.1300/J039v10n04_01

Van Meter, K. C., Christiansen, L. E., Delwiche, L. D., Azari, R., Carpenter, T. E., \& Hertz-Picciotto, I. (2010). Geographic distribution of autism in California: A retrospective birth cohort analysis. Autism Research, 3, 19-29.

Ware, J., Kosinski, M., \& Keller, S. (1994). SF-36 physical and mental heath summary scales: $A$ users manual. Boston, MA: New England Medical Center.

Ware, J., Kosinski, M., \& Keller, S. (1996). A 12-item short form health survey: Construction and scales and preliminary tests of reliability and validity. Medical Care, 34, 220-233. doi:10.1097/00005650-199603000-00003

Ware, J., \& Sherbourne, C. D. (1992). The MOS 36-Item Short-Form Health Survey (SF-36). Medical Care, 30, 473-483.

This publication is protected by US and international copyright laws and its content may not be copied without the copyright holders express written permission except for the print or download capabilities of the retrieval software used for access. This content is intended solely for the use of the individual user.

Source: Families, Systems, \& Health. Vol. 29. (3), Sep, 2011 pp. 232-252)

Accession Number: 2011-21122-003

Digital Object Identifier: 10.1037/a0025341 
